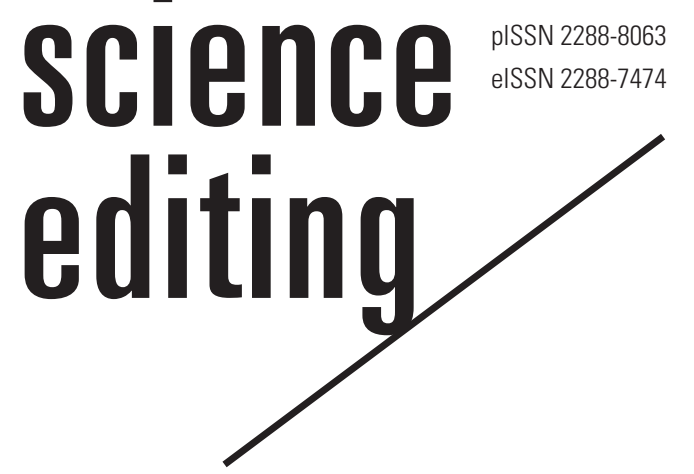

\title{
How to respond to and what to do for papers published in predatory journals?
}

\author{
Aamir Raoof Memon \\ Institute of Physiotherapy and Rehabilitation Sciences, Peoples University of Medical and Health Sciences for Women, \\ Nawabshah, Pakistan
}

\section{Introduction}

Predatory publishing, a destructive phenomenon that has been highlighted and discussed since 2011, is the consequence of the gold (author-pays) open access publishing model [1]. Predatory journals are money-making stations characterized by charging publication fees and an absence of 'true' peer review [2]. These journals and publishers have grown to a very large number in recent years [2,3]. The general assumption is that the most common victims of such journals are young, naive, early career researchers, especially from developing countries, but this may not always be the case [3-5]. Recent evidences suggest that predatory publishing is a global phenomenon affecting authors from both developing and developed countries, and even experienced authors get duped [5,6]. How can we deal with these publishers and how can authors avoid getting duped by them? This essay presents a few incidents to build on for answering these questions.

\section{Story of a Victim of a Predatory Journal}

My first paper was published in December 2014 in a predatory journal without my approval. Although the journal was very new, it claimed to be an international, open access journal with a high impact factor, broad indexing, and a rigorous peer review. The title of the paper published in that journal was "Perceptions, practices, and use of Facebook: a cross-sectional survey on physiotherapy students in Pakistan." Within 2 weeks of submission, the reviewer's comments were received, which did not add anything to improve the content of the manuscript, and the ar-

Received: June 11, 2018 Accepted: July 15, 2018

\section{Correspondence to} Aamir Raoof Memon dpt.aamir@gmail.com

ORCID

Aamir Raoof Memon

https://orcid.org/0000-0002-3203-418X ticle was accepted with an invoice for article processing charges. I did not agree to pay anything to the journal (since the fee was not disclosed ahead of time), nor did I sign a copyright agreement with them. Being unaware of this phenomenon, I was duped at the beginning of my publishing career, and the paper was published in the predatory journal without my consent. I asked myself, "Why did I get duped?"and I started to seek answers to this question. There were a variety of obvious reasons for this, including a lack of proper training and education about publishing, continuous rejections from legitimate journals, and pressure to have the study quickly published in an international, indexed, high impact-factor journal. So, how did I find out that the 
journal was predatory? A few months later, I leaned about Beall's list, which mysteriously disappeared in June 2017 [4]. The publisher was included in Beall's list of potential predatory journals and publishers, and was widely known as a "predatory publishing giant." That claim was further supported when I started learning about predatory publishers and realized that the journal met all the criteria to be termed predatory. In a country where there is a lack of supervision, guidance, and support in terms of research and scientific publishing, one has to struggle to reach one's objectives. In Pakistan, this trend is very common, and government institutions and authorities are generally not concerned about the quality of research or the training of researchers [7]. Another reason for getting duped by the predatory journal was relying on metrics, such as the ResearchGate Impact Factor, that have no worth to the scientific community $[8,9]$. Many early-career researchers, who lack training in scientific publishing, may be victimized by predatory journals through email spams, invitations on social media platforms, and a lack of knowledge about legitimate indexing agencies, publishing practices, and scientometrics.

\section{What Can Be Done to Avoid Getting Duped by Predatory Journals?}

The current point system and the 'publish to perish' mantra have been the major reason for which predatory journals have flourished and succeeded in deceiving researchers [6]. The situation is exacerbated by the lack of training about and control over this issue in higher education institutions at any level [7]. However, it should be noted that not all researchers who publish in such journals are 'prey', as some researchers deliberately publish in such journals and get credit and promotions by adding those papers to their curriculum vitae [10]. Recently, several ways have been proposed to assess the legitimacy of a journal [7,10-12]. In this context, a recent paper with revised terminology for differentiating between low-quality open-access journals and deceptive journals might be helpful [10]. According to this terminology, the term 'predatory' may be inappropriate, and such journals should instead be called 'deceptive journals,' characterized by stating false or misleading information about the peer review process, indexing agencies and journal-level metrics (e.g., impact factor), and article processing charges [10]. In general, such journals intend to dupe authors through deceptive tactics and lack of transparency. Authors, especially early-career and inexperienced researchers who are more likely to be victimized by predatory journals, should use these resources before submitting their work to any journal.

The editors of legitimate journals should also behave responsibly and avoid dubious practices such as unsolicited calls for papers or displaying questionable indexing agencies or journal metrics. I received an email from a legitimate journal from the developed world with a call for papers mentioning its ResearchGate 2015/2016 Journal Impact of 0.84. I have also recently noticed some other legitimate journals that mentioned ResearchGate as an indexing agency, which is not the case $[8,9]$. I contacted the editors of these journals and asked them to change those statements, and my request was accepted. Moreover, I read a paper about predatory journals in an African journal on June 10, 2018; when I checked the list of indexing services mentioned on the journal's website, I found Scribd (https://www.scribd.com/) on the list-which is likewise not an actual indexing service. These practices might be misleading for new and inexperienced researchers and those from developing countries. Journal editors, whether from developing or developed countries, should therefore avoid any practices that could raise doubts about their legitimacy or place them on a list of journals using predatory practices [13]. Recent evidences suggest that pressure to 'publish or perish', a lack of awareness and research proficiency, and the belief that reputable Western journals are prejudiced against authors from the developing world are among the most common reasons for publishing in predatory journals $[6,14]$. Therefore, more effort is needed by reputable journals, organizations, and higher education institutions to make researchers aware of the problem of predatory journals [14].

\section{What Should Be Done With the Literature Published in Predatory Journals?}

Some ways have been proposed to counter predatory journals ethically and legally $[10,11]$, but such mechanisms are challenging to apply globally. However, the recent literature contains some concrete, logical examples and suggestions of how to deal with these journals, which may be generally acceptable to a wider audience. For instance, recent cases of journal phishing and journal hijacking/cybersquatting have been reported, and ways to respond to such practices have been discussed $[11,15]$. Another such case was reported, in which the authors wrote an official retraction letter to a predatory journal, the retraction letter was accepted, and the authors re-wrote their paper and published it in a legitimate journal, the Korean Journal of Chemical Engineering [16]. A recent paper reported a similar incident in which experienced researchers from a developing country mistakenly submitted their work to a predatory journal in 2015 [6]. However, the submission was withdrawn by the authors after a month. The manuscript was then submitted to a legitimate journal in May 2016 and published in February 2017. Months later, the authors came to learn that their manuscript had been mysteriously published in the 2015 issue of a 


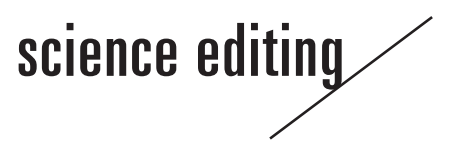

predatory journal of a different publisher. The authors sent a retraction letter to the predatory journal and the paper was removed. What did I do with my paper that I discussed earlier? That paper was published by a predatory giant, and I wrote an e-mail to them in March 2017.

The paper was published in 2014, so why did I retract it in 2017? The reason was to set an example. Papers published in predatory journals are considered "lost science" or "junk science" and I did not want such a paper to be cited in legitimate journals. Although the paper had already been cited in another paper, I did not want to be part of the crime any further, as it has been suggested that such papers should not be cited [17]. Thus, researchers are advised to follow the 5-point stepby-step approach given below.

First, authors should always check the journal before submitting an article and make sure that it is not predatory. Authors are advised to aim for journals indexed in legitimate and reputable databases. This not only ensures that their published work will be preserved, but also improves its visibility and dissemination. If a journal is new or has not been indexed in databases such as Medline/PubMed or Web of Science, there are ways to improve research visibility and dissemination. For instance, researchers can share their work on social networking sites such as Facebook (http://facebook.com), Twitter (http:// twitter.com), ResearchGate (http://researchgate.net/), and other platforms to further enhance its visibility [18].

Second, if authors have submitted their work to a suspicious journal, they should not pay the publication charges without first confirming the legitimacy of the journal. The journal may claim that its office is in the USA or UK, while providing a bank account number in a South Asian country. Therefore, authors should be careful before paying anything to the journal.

Third, if a submitted paper has been accepted by a predatory journal, the authors should never sign a copyright agreement with the journal or publisher. In some cases, writing to the journal to withdraw the submitted or accepted manuscript before its publication may also be successful.

Fourth, if the paper is published online by a predatory journal even after the 3 measures listed above have been taken, the authors may write to the office of the predatory journal and ask them to withdraw the paper from their website. Although the authors are not guaranteed to get a response from a predatory journal, their paper might be taken down from the website. This advice is supported by the Committee on Publication Ethics and has proven to be successful $[6,16,19]$. The predatory journal, in some cases, may ask the authors to pay a withdrawal or retraction fee, but the authors should resist this and continue to insist that the journal retract their article.

Fifth, authors should never support predatory publishing. We must say "no" to predatory journals and publishers. This "no" applies both to publishing with them and to citing their work.

\section{Conclusion}

Authors from developing countries face many problems in scientific publishing due to a lack of funding, support, and training. Much work is ongoing to curtail predatory journals and publishers, but concrete situations, examples, and suggestions must be presented in order to train and educate young researchers and to make the existing community of scholars aware of these situations and ways to deal with them. Everyone must behave responsibly and ethically to restrict the spread of junk science. I hope that one day we will all be able to say "no" to these predatory journals and publishers. The story of the author's journey from being a victim of predatory journals to taking steps to raise awareness against them can be found here: https://www.authoraid.info/en/news/details/1250/.

\section{Conflict of Interest}

No potential conflict of interest relevant to this article was reported.

\section{References}

1. Beall J. Predatory journals exploit structural weaknesses in scholarly publishing. 4Open 2018;1:1. https://doi.org/10.1051/ fopen/2018001

2. Narimani M, Dadkhah M. Predatory journals and perished articles: a letter to editor. Emergency (Tehran) 2017; 5:e49.

3. Memon AR. End of 2016: can we save research from predators in 2017?. Sci Eng Ethics 2017 Jun 14 [Epub]. https:// doi.org/10.1007/s1 1948-017-9915-1

4. Memon AR. Beall's list has vanished: what next? J Orthop Sports Phys Ther 2017;47:219-23. https://doi.org/10.2519/ jospt.2017.0202

5. Clark J. Letter to the Editor. Predatory journals: bad for all but especially authors from low and middle income countries. Acta Med Port 2018;31:184-5. https://doi.org/10.20344/ amp.10489

6. Memon AR. Publish or perish: a sign of caution for authors to avoid predatory journals. J Pak Med Assoc 2017;67:822.

7. Memon AR. Research publications and education in Pakistani medical universities: avoiding predatory journals and improving the quality of research. J Pak Med Assoc 2017;67:830-3.

8. Memon AR. ResearchGate and impact factor: a step further on predatory journals. J Pak Med Assoc 2017;67:148-9. 
9. Memon AR. ResearchGate is no longer reliable: leniency towards ghost journals may decrease its impact on the scientific community. J Pak Med Assoc 2016;66:1643-7.

10. Eriksson S, Helgesson G. Time to stop talking about 'predatory journals'. Learn Publ 2018;31:181-3. https://doi.org/10.1002/ leap. 1135

11. Park SP, Lee EY, Suh JH. Arbitral action and preventive methods against predatory journal practice. Sci Ed 2018; 5:49-52. https://doi.org/10.6087/kcse.118

12. Memon AR. Predatory journals spamming for publications: what should researchers do?. Sci Eng Ethics 2017 Aug 16 [Epub]. https://doi.org/10.1007/s11948-017-99556

13. Memon AR, Waqas A. Indexing by bibliographic databases of journals published in the developing world. Sci Eng Ethics 2017 Mar 20 [Epub]. https://doi.org/10.1007/s11948017-9898-y

14. Kurt S. Why do authors publish in predatory journals?. Learn Publ 2018;31:141-7. https://doi.org/10.1002/leap.1150
15. Choi J. Impersonation of Journal of Electrical Engineering \& Technology journal website. Sci Ed 2017;4:76-9. https:// doi.org/10.6087/kcse.99

16. Balehegn M. Increased publication in predatory journals by developing countries' institutions: what it entails? And what can be done?. Int Inf Libr Rev 2017;49:97-100. https:// doi.org/10.1080/10572317.2016.1278188

17. Dadkhah M, Lagzian M, Borchardt G. Questionable papers in citation databases as an issue for literature review. J Cell Commun Signal 2017;11:181-5. https://doi.org/10.1007/s12079016-0370-6

18. Tripathy J, Bhatnagar A, Shewade HD, Kumar AM, Zachariah R, Harries AD. Ten tips to improve the visibility and dissemination of research for policy makers and practitioners. Public Health Action 2017;7:10-4. https://doi.org/10.5588/ pha. 16.0090

19. Dadkhah M, Darbani SM. What can authors do for the papers they published in predatory journals?. Pol Arch Med Wewn 2016;126:574-5. https://doi.org/10.20452/pamw.3485 